Article

\title{
The Environmental Attitudes and Behaviours of European Golf Tourists
}

\author{
Jesús Manuel López-Bonilla *, María del Carmen Reyes-Rodríguez and \\ Luis Miguel López-Bonilla
}

Department of Business Administration and Marketing, Universidad de Sevilla, 41018 Sevilla, Spain; mcreyes@us.es (M.d.C.R.-R.); luismi@us.es (L.M.L.-B.)

* Correspondence: lopezbon@us.es; Tel.: +34-954-554-438

Received: 25 May 2018; Accepted: 26 June 2018; Published: 28 June 2018

\begin{abstract}
Environmental attitudes and behaviours have received relatively little attention in golf tourism, compared to other tourism research areas. Golf tourism provides products and services based on nature, and they should focus on the environment. Golf has become increasingly important in the development of European tourism within the last decade. Moreover, golf is one of the primary motivations for European tourists in the sports tourism sector. This study is based on a sample of 431 golf tourists, from different nationalities, who visit Andalusia, Spain. This research examines the relationship between environmental attitudes and behavioural intentions for three subsamples of European nationalities: British, German, and Spanish. This relationship was corroborated in the three subsamples. However, the national citizenship of European golf tourists was not a moderator effect on the relationship between environmental attitudes and behavioural intentions.
\end{abstract}

Keywords: environmental concern; environmental intention; golf; tourist behaviour; cross-cultural analysis; nationality

\section{Introduction}

Since the end of the 1960s, the Mediterranean coasts have been popular vacation destinations. However, playing golf has become increasingly important in the development of European tourism within the last decade [1]. There has been increased popularity of golf among tourists, due to motivations for golf-related trips or leisure opportunities to share with business colleagues, friends, or family [2]. Usually, those tourists, who include playing golf in their trips, make a high average expenditure, which is why this sport has become a very desirable type of demand for tourist areas. However, the golf supply should be done rationally, respecting the environment where it is located, to maintain its social, economic, and environmental balance in the future.

Golf tourism provides products and services based on nature, and they should focus on the environment. Specifically, the request for a sustainable environmental management of golf courses in Andalusia is increasing. Recently, the government of Andalusia has tightened the current legislation on the environmental conditions that golf courses must meet. Likewise, the concept of "tourist golf courses", which requires specific environmental qualifications to be declared as such, was created in this Spanish region.

Sustainable development is an important topic for golf course and golf resort development [3]. The expansion of golf development has been very fast in recent decades in the world, but the golf courses are highly controversial in environmental terms [4]. However, Kim and Ritchie [5] suggested that golf tourists are attracted by extrinsic motivators, such as the "natural environment". The knowledge of the behavioural patterns and processes that motivate and define the choices of golf tourists can help immensely in the environmental management of golf courses. 
The main objective of this paper is twofold: (1) to examine the influence of environmental attitudes on environmental intentions in golf tourists; and (2) to analyse whether culture, through nationality, moderates the relationship between environmental attitudes and environmental intentions in golf tourists.

Andalusian golf courses have adopted an environmental regulation more rigorous in recent years. The golf courses can be declared of tourist interest by the Andalusian Government if they comply with the principles of sustainable development. This procedure to obtain the declaration of tourist interest aims to promote the improvement and respect for the environment and the restoration and protection of the landscape [6-8]. For this, the golf course managers should observe the environmental attitudes and behaviours of golf players. In particular, the golf courses that are located in tourist zones can be more vulnerable because they are frequented by a greater heterogeneity of individuals coming from different places of Spain and other countries, especially from European countries. The environmental concern of these golfers can have a wide impact on the attractiveness and competitiveness of golf tourism in Andalusia. Hence, this paper allows exploring the environmental attitudes and behaviour from a tourist's perspective. Following Wilhelm-Richmann, Cowling and Difford [9] and Minoli, Goode and Metcalfe [10], an insightful grasp of environmental attitudes and behaviours of golf tourists is imperative to enable conservation practitioners to interpret better the barriers to carrying out environmental management programmes.

While golf does take place outdoors, it is in a heavily altered environment. However, golf courses have positive and negative environmental impacts [11]. It is important to understand that sustainability is not just an environmental issue. In this sense, as Completo and Gustavo [12] pointed out, the research on golf is essentially limited to environmental aspects, and socioeconomic and cultural ones are usually neglected. According to Woodside [13], golf can play an important role in the process of environment qualification, in the sustainable economic development and in the increasing of the quality of life of the host communities. Thus, golf players may represent a key element to promote and support a pro-environmental behaviour. Therefore, it is necessary to explore the current mindsets of golfers toward sustainability.

The study of golf tourism has emerged as an interesting research field [1], as very recent studies have demonstrated [14-19]. The present work tries to contribute to literature on the environmental attitudes and behaviours of golf tourists. As Han, Yoon and Woods [17] noted, the role of environmental consciousness, in the decision-making process, has not been examined for the golf industry. Furthermore, there is virtually no literature that has explored cross-cultural differences in attitudes towards environmentally responsible tourism [20]. More recently, Li [21] carried out a meta-analysis on cross-cultural tourist research. In this state-of-the-art journal publication, an extensive range of research topics inquired in a cross-cultural context, but only seven studies conducted within the context of attitude and behavioural intention. Therefore, this paper addresses this gap in the literature and contributes knowledge on environmental attitudes and behaviours in the specific area of golf tourism. Moreover, the results from this study can assist destination marketers in developing marketing and managerial strategies.

\section{Research Model and Hypotheses Testing}

Golf tourism generates significant profits, but golf courses are frequently questioned about their close relationship with the environment and, consequently, their possible adverse impact on it. In this regard, Correia et al. [22] argued that both managers and tourists need to be aware of the importance of sustainable tourism practices. Research on sustainability in golf has increased in recent years from the perspective of golf courses [15,23-28]. Hence, there is a substantial literature on golf courses on their negative environmental impacts, especially with respect to excessive water use [29,30], environmental pollution [31], chemical inputs [32,33], and effects on wildlife and habitat [34,35].

Environmental attitudes and behaviours have been extensively studied in the outdoor recreation literature [36-42] as well as in sustainable tourism literature [20,43-47]. However, the sustainability of 
golf from the consumer's perspective has been very little studied $[10,18,48,49]$. In this case-from the visitor's perspective- the studies have focused on the behaviour of golf tourists, especially based on the motivation of visitors $[5,50,51]$, intentions to return to the golf destination $[2,52,53]$, destination selection [54], determinants of golf tourists satisfaction [55,56], image of the golf destination [57], price [16], golf supply and demand [58], gender [59-61], and profile of golf travellers [19,62-64]. Nevertheless, environmental attitudes and behaviours have received relatively little attention, compared to other tourism research areas. Moreover, as Kang and Moscardo [20] suggested, there has been very little research into tourists' awareness of, and interest in, responsible travel behaviours. Very limited knowledge exists about who these ecologically friendly people are [65].

Lee and Moscardo [66] pointed out that environmentally aware consumers might be more likely to have pro-environmental conducts than other users who are only exposed to green friendly practices by businesses at the destination. However, having a positive attitude does not develop as a good indicator of making environmentally sustainable vacation choices [43]. In this sense, Roberts and Bacon [67] suggested that the past research had suffered from poor attitude-behaviour consistency. Currently, researchers are also challenged by the gap between ecological attitudes and corresponding behaviours [68-72]. Hence, the usual findings reveal either a moderate relationship between environmental attitude and behaviour [73-77], or a weak relationship [78-81]. Moreover, there are several studies that report no such relationship at all [82-85].

Nevertheless, recent tourism studies have supported the firm correlation between attitudes and behaviours [86-90]. However, other studies have not supported this association [91,92] nor demonstrated that this link is relatively weak [93-95].

Environmental attitude is used as either a multiple or single component approach. Kinnear, Taylor, and Ahmed [96] showed that ecological concern was similar in context to environmental responsibility and was composed of two dimensions: (i) an attitude that must show a concern for the environment; and (ii) a purchasing conduct that should be consistent with the care of the environment. They further indicate that the level of ecological concern is a function of both attitudes and behaviours.

As an alternative to the multiple component approaches, Dunlap and Van Liere [97] developed the new environmental paradigm (NEP). This scale is a single component measure of environmental attitude. However, Kaiser, Wölfing and Fuhrer [98] indicated that the relationship between the NEP and ecological behaviour ranges from strong, through moderate to weak or no relationship at all. There are also the clear results from the study of Jackson [99] where correlations between the scales vary for several groups of stakeholders in the United Kingdom (UK) tourism sector. As Wolf-Watz, Sandell and Fredman [100] suggested, its usefulness is questioned, because of the concerns regarding a weak link with environmental conducts.

Therefore, a simple model is proposed, linking environmental attitudes and behavioural intentions, so that the environmental concern of the golf tourist exerts direct influence on his or her ecological orientation toward choosing a golf course that is sustainable and respects the environment. The present study was based on a comparison among European golf tourists. The conceptual model is shown in Figure 1. Hence, this model included two fundamental hypotheses:

Hypothesis 1 (H1). The environmental attitudes may influence the environmental behaviour intentions in golf tourists.

Hypothesis 2 (H2). The national culture may act as a moderator on the relationship between environmental attitudes and environmental behaviour intentions in golf tourists. 


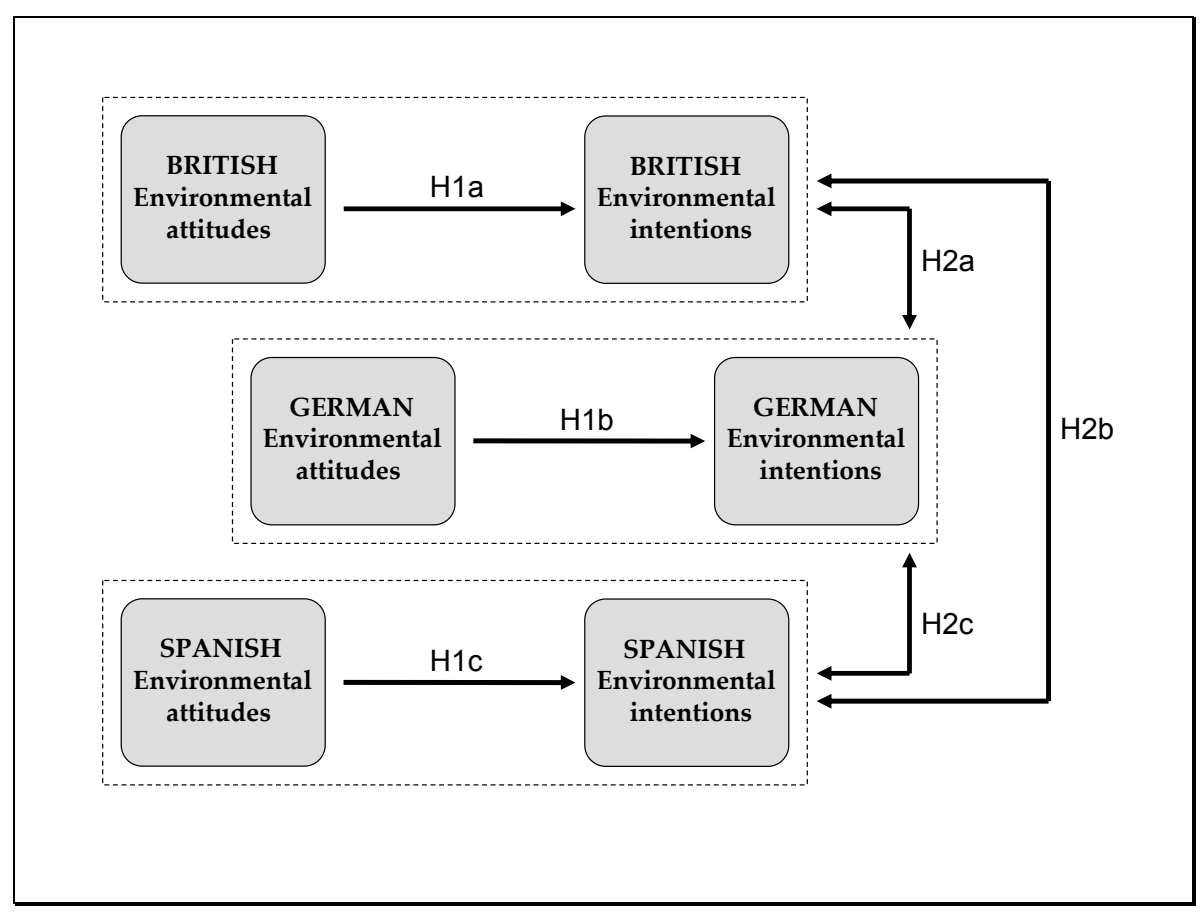

Figure 1. Conceptual model.

It intended to confirm whether there are significant differences in the environmental attitudes and behaviours of German, British, and Spanish golf tourists. As Wolf-Watz, Sandell and Fredman [100] indicated, environmental attitude refers to an awareness of environmental problems and dedication to protection - often including self-reported behaviour-whereas, environmental behaviour means the actions taken based upon particular attitudes. Thereby, this study associated the environmental concern with the attitudes of the golf tourists, whereas the environmental commitment was linked to the intention of using a sustainable golf course.

The environmental responsibility of golf tourists was measured by two scales: (a) the RNEP (Revised New Ecological Paradigm) scale; and (b) the TEO (Tourist Ecological Orientation) scale. The relationship between both scales has already been empirically checked. According to Kinnear, Taylor and Ahmed [96], these two scales can represent two consecutive stages in the process of choosing a golf course that is committed to the environment. These authors indicated two dimensions in environmental responsibility: (1) attitude; and (2) buying behaviour. In this work, the concept of attitude was understood as an evaluative judgment [101,102]. The definition given by Eagly and Cheiken [101] (p. 1) was of particular interest: "attitude is a psychological tendency, which is expressed by evaluating a particular entity with some degree of favour or disfavour".

According to Fishbein and Ajzen [103], the cause closest to the buying behaviour is the intention to do it; in addition, attitudes influence behaviours through their influence on intentions. An intention represents a personal motivation, as for having a plan that involves the realisation of an effort to carry out a behaviour [104]. Therefore, in this research, it can test whether the environmental attitudes have a significant influence on the intention of using a golf course that is sustainable or respects the environment by nationality. Hence, it formulates the following specific hypotheses:

Hypothesis 1a (H1a). The environmental attitudes directly influence the environmental behaviour intentions in British golf tourists.

Hypothesis $\mathbf{1 b}(\mathbf{H 1} \mathbf{b})$. The environmental attitudes directly influence the environmental behaviour intentions in German golf tourists. 
Hypothesis 1c (H1c). The environmental attitudes directly influence the environmental behaviour intentions in Spanish golf tourists.

Furthermore, cultural differences are studied as a moderator effect on the relationship between environmental attitudes and behavioural intentions. The analysis of culture related research in marketing extensively focuses on cultural differences between countries [105]. Cultural distance influence international marketing mix decisions [106]. Following Kim, Wen and Doh [107], "countries" were used as a proxy for culture. Cross-cultural comparative research usually involves the comparisons of different countries [108]. Minkov and Hofstede [109] suggested that, while the use of nation has many supporters as unit of measure in cross-cultural studies [110], it has also received several criticisms [111]. This study was limited to the dominant culture of participants, because there may be large sub-cultures within individual countries [112].

The literature review showed that there are diverse studies on the pro-environmental behaviour in which cultural differences are found between nations [20,113-115]. Therefore, specific hypotheses are stated as follows:

Hypothesis 2a (H2a). Cultural differences between British and German golf tourists moderate the relationship between environmental attitudes and behavioural intentions.

Hypothesis $\mathbf{2 b}(\mathbf{H} 2 \mathbf{b})$. Cultural differences between British and Spanish golf tourists moderate the relationship between environmental attitudes and behavioural intentions.

Hypothesis 2c (H2c). Cultural differences between German and Spanish golf tourists moderate the relationship between environmental attitudes and behavioural intentions.

\section{Materials and Methods}

\subsection{Participants and Data Collection}

A sample of 431 golf tourists from three nationalities (British, German, and Spanish) completed a questionnaire on their environmental attitudes and behaviours. These players are tourists visiting the destination where the golf course in which they have responded to the survey is located. All Spanish respondents were also tourists, relative to the location of the study. The sample is clearly diversified, regarding the variables of age, gender, and education level.

The questionnaire was handed out on 15 golf courses in Andalusia, by a team of interviewers. A professional survey consultant conducted the interviews. Andalusia is the Spanish region with the largest number of golf courses-approximately one hundred golf courses. Fifteen golf courses were selected using a convenience sampling method. These 15 golf courses were considered to be relevant because all of them were located in coastal zones with the greatest tourist influx in Andalusia, such as the Costa del Sol in Málaga and Almería, Spain, and the Costa de la Luz in Cádiz and Huelva, Spain.

\subsection{Variables}

The relationship between environmental attitudes and behavioural intentions was measured by two scales in this study: (1) the RNEP scale; and (2) the TEO scale. The RNEP scale, developed by Dunlap, Van Liere, Mertig and Jones [116], consists of 15 items. The TEO scale, developed by Uriely, Reichel and Shani [117], also consists of 15 items. In the present study, RNEP refers to the general environmental attitudes that the golf tourist may have. In contrast, TEO indicates the ecological orientation of the visitor toward the golf course he/she decided to play.

The items used in each scale of this study are described in Table 1 . These items were selected by a panel of four academic experts for this purpose. The experts carried out the task of analysing, as a discussion group, the content of the two scales. They selected five and eight items from the RNEP 
and the TEO scales, respectively. López-Bonilla and López-Bonilla $[18,48]$ have analysed the validity and reliability of both scales, and they have called Brief Ecological Paradigm scale (BEP) and Revised TEO scale (RTEO). On the one hand, the five items from the BEP scale provided a balanced measure of the following four facets identified in the RNEP scale of Dunlap et al. [116], from an ecocentric or pro-environmental perspective: (1) the possibility of an eco-crisis (Items 1 and 5); (2) rejection of exemptionalism (Item 2); (3) the reality of limits to growth (Item 3); and (4) the fragility of nature's balance (Item 4). On the other hand, López-Bonilla and López-Bonilla $[18,48]$ suggested that the RTEO scale should consist of four elements, which correspond to items on environmental concern, recycling, regulations, and education. A five-point Likert scale was used to measure our variables, where: strongly disagree is 1 and strongly agree is 5 . Both scales are a reliable and fast form approach to measuring environmental attitudes and behaviours $[18,48]$. In this sense, the use of short-form measure can achieve a greater efficiency for researchers [118,119].

Table 1. Items of the two scales.

\begin{tabular}{|c|c|c|}
\hline Variables & Items & Statements \\
\hline \multirow{5}{*}{$\begin{array}{l}\text { Environmental attitudes } \\
\qquad \text { (BEP scale) }\end{array}$} & BEP1 & Humans severely abusing the environment \\
\hline & BEP2 & Despite our special abilities, humans are still subject to the laws of nature \\
\hline & BEP3 & The earth is like a spaceship with very limited room and resources \\
\hline & BEP4 & The balance of nature is very delicate and easily upset \\
\hline & BEP5 & $\begin{array}{l}\text { If things continue on their present course, we will soon experience a major } \\
\text { ecological catastrophe }\end{array}$ \\
\hline \multirow{4}{*}{$\begin{array}{l}\text { Environmental intentions } \\
\text { (RTEO scale) }\end{array}$} & RTEO1 & Environmental concern of their managers \\
\hline & RTEO2 & Recycles waste \\
\hline & RTEO3 & Legal regulations of the environmental are met \\
\hline & RTEO4 & Educates to preserve the quality of the environment \\
\hline
\end{tabular}

\subsection{Analytical Procedure}

The authors of this research conducted the psychometric analysis through latent structural analysis and internal consistency analysis. This methodology was followed to improve indicator debugging to obtain a greater guarantee of robustness in the absolute scale.

Partial Least Square Structural Equation Modelling (PLS-SEM) is a variance based Structural Equation Modelling (SEM). PLS-SEM is a limited estimation method denominated in this way by dividing the list of parameters to be estimated into various subsets, using multiple linear regressions, which employ the algorithm of the Ordinary Least Squares (OLS) [120]. The primary objective of PLS-SEM is to explain the variances of the endogenous variables, which is why it tends to be a useful tool for finding the cause that significantly determines the behaviour of these variables. The PLS-SEM does not need any parametric conditions, which are compulsory in covariance-based SEM analysis (CB-SEM); thus, this technique is particularly appropriate in the case of small samples with non-normal data [121]. For each nationality (i.e., British, German, and Spanish), the structural model is analysed as follows: Use Intention $=\beta 0+\beta 1$ Attitude $+\varepsilon$.

\section{Results}

Table 2 details the descriptive data of the two scales. It lists the mean values and standard deviations by country. The average values of the three nationalities analysed are also included. In general, the scores are high on both scales (above three), except for British tourists, who scored slightly below three (3). Likewise, the BEP scale outscores the RTEO scale in all nationalities. On the other hand, Spanish players score above the BEP scale's mean value, while only British players score below the RTEO scale's mean value.

The analysis of the proposed relationships starts from the study of the measurement scales. Thereby, the relationships between the two scales (BEP and RTEO) and their items are analysed to test the convergent and discriminant validity. Three metric tests were assessed to test the convergent 
validity: indicators reliability (IR), composite reliability (CR) and the average variance extracted (AVE) from the two scales.

Table 2. Descriptive statistics of the variables: Means and Standard deviations (SD).

\begin{tabular}{ccccc}
\hline \multirow{2}{*}{ Variables } & British & German & Golf Tourists & \\
& $(\boldsymbol{n}=\mathbf{6 7})$ & $(\boldsymbol{n}=\mathbf{7 7})$ & $(\boldsymbol{n}=\mathbf{2 8 7})$ & 3 Countries \\
\hline Environmental attitudes & 3.72 & 3.53 & 4.08 & 3.79 \\
(BEP scale) & $(0.97)$ & $(1.13)$ & $(0.88)$ & $(0.23)$ \\
Environmental intentions & 2.96 & 3.27 & 3.32 & 3.23 \\
(RTEO scale) & $(1.23)$ & $(1.19)$ & $(1.20)$ & $(0.19)$ \\
\hline
\end{tabular}

First, the IR was assessed, based on the two observed scales. As shown in Table 3, most of the loadings are greater than 0.707, according to Chin [121]. Only one item (BEP2) was removed for Spanish players. Likewise, two items (BEP1 and BEP2) were removed in the British sample, according to Chin [121] and Keil et al. [122]. These authors argued that a reliability grade of less than 0.707 can be acceptable, on the condition that it remains above 0.5 , and that the other indicators of the construct have high scores. In this study, these circumstances exist; hence, this item remained an indicator on the BEP scale.

Table 3. Loadings of the indicators of the latent variables.

\begin{tabular}{ccccc}
\hline Variables & Items & British & German & Spanish \\
\hline & BEP1 & 0.687 & 0.832 & 0.844 \\
Environmental attitudes & BEP2 & 0.677 & 0.845 & - \\
(BEP scale) & BEP3 & 0.860 & 0.888 & 0.781 \\
& BEP4 & 0.899 & 0.895 & 0.887 \\
& BEP5 & 0.808 & 0.829 & 0.857 \\
\hline \multirow{3}{*}{ Environmental intentions } & RTEO1 & 0.909 & 0.885 & 0.902 \\
(RTEO scale) & RTEO2 & 0.911 & 0.896 & 0.834 \\
& RTEO3 & 0.950 & 0.944 & 0.912 \\
& RTEO4 & 0.906 & 0.940 & 0.863 \\
\hline
\end{tabular}

Table 4 details the other two measurements for the convergent validity: the composite reliability (CR) and the average variance extracted (AVE). It can be considered that the values of the CR evidently exceed the recommended minimum of 0.7 in each of the nationalities. At the same time, the values of the AVE appear to exceed the recommended minimum, since they are greater than 0.5 [123].

Table 4. Average variance extracted (AVE) and Composite reliability (CR).

\begin{tabular}{ccccc}
\hline Variables & Coeff. & British & German & Spanish \\
\hline Environmental attitudes & AVE & 0.626 & 0.737 & 0.616 \\
(BEP scale) & CR & 0.892 & 0.840 & 0.886 \\
\hline Environmental intentions & AVE & 0.845 & 0.840 & 0.771 \\
(RTEO scale) & CR & 0.956 & 0.940 & 0.931 \\
\hline
\end{tabular}

This analysis was completed with the testing of the discriminant validity. As Chin [121] suggested, the discriminant validity consists of making sure that each item correlates more strongly with the items of the same construct than with other items of other latent variables. Table 5 gathers these data, with which the discriminant validity between the measurement scales was proven. 
Table 5. Discriminant validity of the latent variables.

\begin{tabular}{cccc}
\hline Variables & BEP Scale & RTEO Scale & Nationalities \\
\hline Environmental attitudes & 0.791 & 0.396 & British \\
(BEP scale) & 0.858 & 0.540 & German \\
& 0.785 & 0.470 & Spanish \\
\hline Environmental intentions & & 0.919 & British \\
(RTEO scale) & & 0.917 & German \\
& & 0.878 & Spanish \\
\hline
\end{tabular}

The empirical study concluded with the structural analysis of the relationship between attitudes and behavioural intentions. These results are detailed in Table 6. It observes that the BEP scale significantly influence the RTEO scale in all the nationalities; that is, environmental attitudes significantly influence on environmental behaviour intentions. Hence, Hypotheses H1a, H1b, H1c, and H1d were confirmed. To complete this structural analysis, it can be observed that the variances $\left(R^{2}\right)$ of the dependent variables are explained by the independent variables in each of the three nationalities. German tourists present the strongest relationship between attitudes and intentions of using golf courses that respect the environment $\left(R^{2}=0.292\right)$, followed by Spanish tourists $\left(R^{2}=0.220\right)$ and British tourists $\left(R^{2}=0.157\right)$. All of these results exceed the minimum value recommended by Falk and Miller [124], that is, an $R^{2}$ value equal to or greater than 0.1 .

Table 6. Relationship between environmental attitudes and behavioural intentions.

\begin{tabular}{ccccc}
\hline Relationship & Coeff. & British & German & Spanish \\
\hline Environmental attitudes $\rightarrow$ Environmental intentions & Path & 0.396 & 0.540 & 0.470 \\
$(\mathrm{BEP} \rightarrow$ RTEO) & $t$ & 3.255 & 6.706 & 10.203 \\
& $\mathrm{R}^{2}$ & 0.157 & 0.292 & 0.220 \\
\hline
\end{tabular}

Finally, the differences between tourists from different nationalities by comparing the paths were checked. The bootstrap re-sampling method was used, applying the following formula:

$$
=\frac{P a t h_{\text {sample_1 }}-P a t h_{\text {sample_2 }}}{\left[\sqrt{\frac{(m-1)^{2}}{m+n-2}} * S E_{\text {sample_1 }}^{2}+\sqrt{\frac{(n-1)^{2}}{m+n-2}} * S E_{\text {sample_2 }}^{2}\right] *\left[\sqrt{\frac{1}{m}+\frac{1}{n}}\right]}
$$

where $m$ and $n$ are the numbers of elements within each group, and $S E$ is the standard error estimates from each cluster. The significance of the difference was obtained by a $t$-test, that is, through the comparison between the values of the formula with the $t$-value of a $t$-Student distribution with $m+n-2$ freedom degrees. The results are shown in Table 7 .

Table 7. Culture differences between nationalities.

\begin{tabular}{cccccc}
\hline Comparisons & $\begin{array}{c}\text { Path Value } \\
\text { Sample 1 }\end{array}$ & $\begin{array}{c}\text { Path Value } \\
\text { Sample 2 }\end{array}$ & $\begin{array}{c}\text { Difference between } \\
\text { Path Values }\end{array}$ & t-Statistic & $p$-Value \\
\hline British-German & 0.540 & 0.396 & 0.144 & 1.040 & 0.300 \\
British-Spanish & 0.470 & 0.396 & 0.073 & 0.669 & 0.504 \\
German-Spanish & 0.540 & 0.470 & 0.071 & 0.726 & 0.469 \\
\hline
\end{tabular}

No significant cultural differences were observed between golf tourists when comparing, two-by-two, the path values of each one of the nationalities. Hence, the invariance of the model and its independence on citizenship was proven (at least in these three geographical European areas). Therefore, Hypotheses H2a to $\mathrm{H} 2 \mathrm{c}$ are rejected. Figure 2 illustrates the results. 


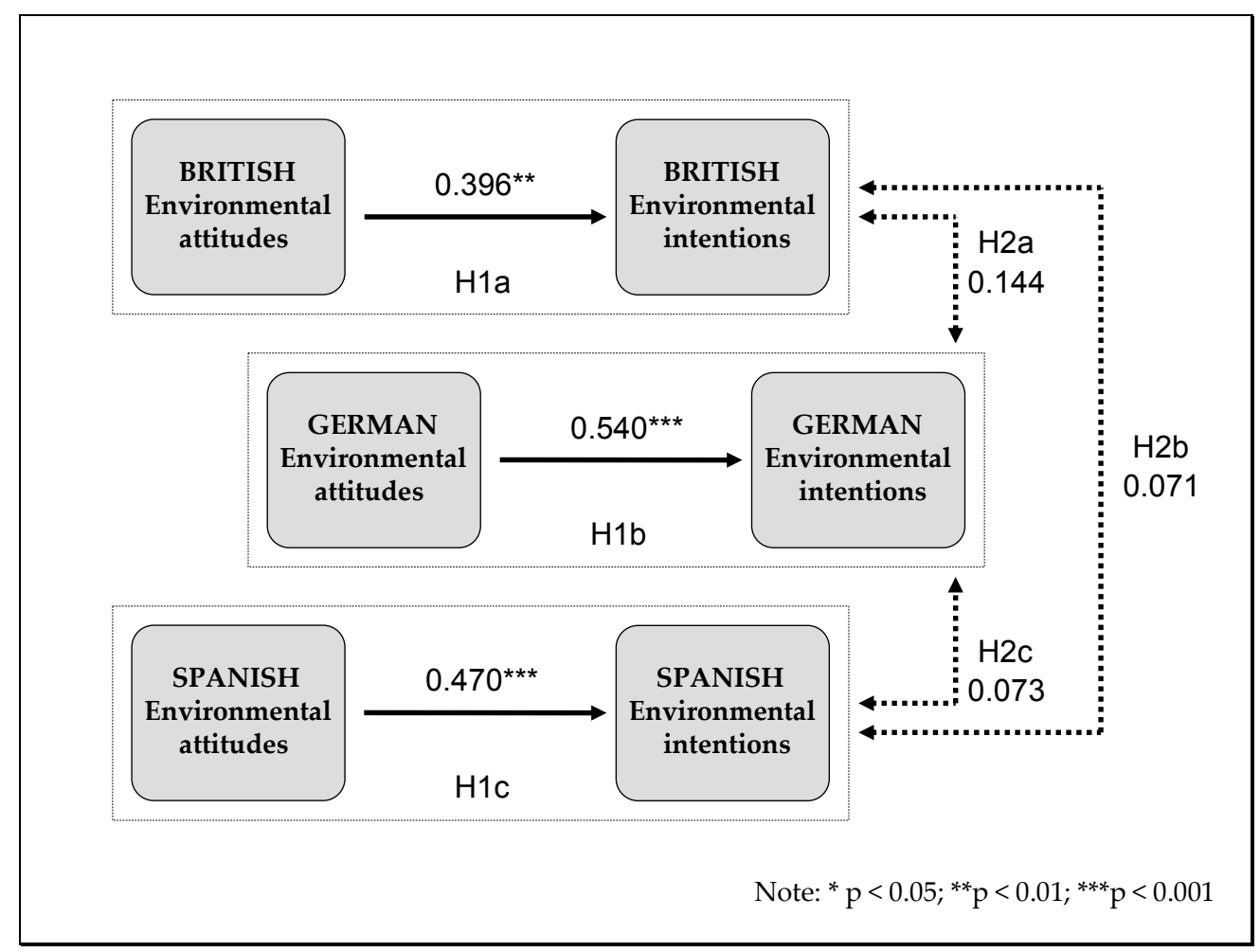

Figure 2. Results of the structural model analysis.

\section{Discussion and Conclusions}

\subsection{Theoretical Implications}

There are still few studies about the relationship between environmental attitudes and behaviours of golf tourists. The present study compared the environmental attitudes and behaviours of golf tourists from different nationalities who visit Andalusia (Spain). This region is one of the most famous golf destinations in Europe. The demand for golf tourism in Andalusia comes from very different countries. This study focused on the most frequent golf tourists currently in Andalusia: German, British, and Spanish tourists. Thereby, the comparative analysis performed, regarding those three European cultural areas, is clearly differentiated.

The BEP scale and the RTEO scale were adapted to this study and were composed of five and four items, respectively. The reliability of both scales, within the three subsamples of tourists, was checked. The BEP scale was considered as the environmental attitude of the visitor, whereas the RTEO scale represented the intention of using a golf course that is sustainable or respects the environment.

The BEP scale has higher scores than the RTEO scale. The differences in scores between both scales may be because the environmental intention is closer to the actual behaviour of the individual. In contrast, the environmental attitudes are based upon a more idealised perspective. However, German tourists have very similar scores on both scales, which might represent a closer relationship between the emotional and conative aspects in these tourists.

The results indicate that Spanish tourists have the highest scores on the BEP scale, followed by British tourists. However, Spanish tourists have the highest scores on the RTEO scale, followed by German tourists. It is possible that Spanish tourists have a greater environmental responsibility on golf courses, due to reasons of culture and tradition, since they feel more identified with their country and the environmental policy of public administrations for golf courses. These results are consistent with the study of Carrus, Bonaiuto and Bonnes [125], which indicated that regional identity plays a significant role in environmental behaviours. As Dolnicar, Crouch and Long [65] suggested, it is likely 
that identification levels are low in the tourism context, in general, particularly when tourists visit for the first time.

A causal analysis confirmed the relationship between environmental attitudes and behavioural intentions. Previous research on this context has been inconclusive. In the present study, this relationship between both constructs was confirmed in the three subsamples of nationalities, which is consistent with some studies [86-90]. Therefore, in contrast to findings from other studies [82,91,92], there is a strong association between environmental attitude and ecological behaviour in all groups of study.

As an explanation for this finding, following Stern and Oskamp [126], environmental concern-i.e., an attitude towards facts-correlates with an environmentally responsible behaviour, only if: (1) the attitude and behaviour measure at the same level of specificity; and (2) if the behaviour is easy to perform. As Choi, Ritchie and Fielding [86] pointed out, the conceptual differentiation between general and specific measures of psychological characteristics helps researchers understand why there are, sometimes, weak relationships between general attitudes and behavioural intentions.

No cultural differences were observed in this study between European golf tourists, in contrast with similar studies in the area of tourism $[20,115]$. This result may be because golf tourists usually have education and income levels higher than the average population. The education and income levels of individuals are two factors that influence their environmental orientation directly [65]. However, it could be interpreted that the European culture is also increasingly homogeneous in some aspects, such as environmental attitudes and behaviours. In contrast, the studies of Hudson and Ritchie [115] and Kang and Moscardo [20] were carried out with samples of countries from different continents. In any case, the European Union must reinforce this favourable mentality of European citizens toward the environment. In this sense, Venaik and Brewer [105] proposed a universal culture model that is based on similarities among people across nations.

\subsection{Managerial Implications}

A segment of the consumer population is inclined to make decisions in an environmental manner. It is likely that the ecological awareness of individuals reflects their purchasing behaviours. To be more competitive, golf courses must incorporate ecologically friendly management that provides pleasurable opportunities for golf players and tourists.

As Roberts and Bacon [67] pointed out, if public policymakers and marketers are to be successful in encouraging ecological consumers, among their target markets, it will be essential that they have a clear understanding of the antecedents of such behaviour. The marketing of golf course managers and the Andalusian government that promotes golf tourism in Europe, must consider this cultural homogeneity in those target markets that are more relevant to Spain. Following Venaik and Brewer [105], managers should always remain vigilant, regarding meaningful cultural differences relating to their products or services, but they should also be aware of similarities among people across countries. These similarities can provide significant opportunities to develop a more globalised marketing strategy for the organizations. However, the possibility that there are differences in non-European countries, such as the United States and Japan, should be analysed too, as they are also very crucial tourism emitter countries in the entire world.

\subsection{Limitations and Future Research Directions}

This study has some limitations, which point to some avenues for future research. The present study has analysed the relationship between environmental attitudes and behavioural intentions for three subsamples of European nationalities: British, German, and Spanish. The sizes of the samples for British and German tourists are small, but PLS-SEM is very useful in generating estimates, even with a very small sample size. PLS-SEM has more power than other techniques at a small sample size [127]. According to Hair, Ringle and Sarstedt [128], the PLS-SEM minimum sample size should be equal to ten times the largest number of a structural path directed at a particular latent construct in the structural model. In this sense, the British and German sample sizes are congruent with the rule 
of thumb recommended by Hair, Ringle and Sarstedt [128]. Future research should also examine this relationship in other cultures and nationalities. However, the sample sizes of the British and German golf tourists are smaller than Spanish golf tourists. In this sense, the sampling range should be greater in future research. Another limitation found in this study was the disparity in gender distribution of the sample population. Women generally worry more about environmental issues, and their attitude towards the environment is usually more positive [67].

On the other hand, this research focused on the relationship between attitudes and behavioural intentions rather than behaviours directly. However, it is accepted in other empirical studies that an ecological behaviour intention is a significant indication of ecological behaviour. Therefore, further studies, with larger sample sizes, are needed to confirm the regional identity to play a significant role in environmental behaviour. It would be interesting to study first-visit tourists against re-visiting tourists. In this last case, visitors may be more closely linked to familiar destination and, therefore, they may identify with a greater environmental responsibility at that destination. Moreover, future studies should examine other cultural dimensions (e.g., individualism, masculinity, and power distance) and other factors that may influence behavioural intention, such as environmental values, social norms, and perceived control.

Author Contributions: Conceptualization, J.M.L-B., M.C.R-R. and L.M.L-B.; Methodology, J.M.L-B., M.C.R-R. and L.M.L-B.; Software, J.M.L-B., M.C.R-R. and L.M.L-B.; Validation, J.M.L-B., M.C.R-R. and L.M.L-B.; Formal Analysis, J.M.L-B., M.C.R-R. and L.M.L-B.; Investigation, J.M.L-B., M.C.R-R. and L.M.L-B.; Resources, J.M.L-B., M.C.R-R. and L.M.L-B.; Data Curation, J.M.L-B., M.C.R-R. and L.M.L-B.; Writing-Original Draft Preparation, J.M.L-B., M.C.R-R. and L.M.L-B.; Writing-Review \& Editing, J.M.L-B. and L.M.L-B.; Visualization, J.M.L-B., M.C.R-R. and L.M.L-B.; Supervision, J.M.L-B and L.M.L-B.

Conflicts of Interest: The authors declare no conflict of interest.

\section{References}

1. Pastor, J.T.; Del Campo, F.J.; Vidal, F.; Pastor, D.; Agulló, A. Analysis of the efficiency of golf tourism via the Internet. Application to the Mediterranean countries. Curr. Issues Tour. 2015, 18, 595-608. [CrossRef]

2. Hutchinson, J.; Wang, Y.; Lai, F. The impact of satisfaction judgment on behavioral intentions: An investigation of golf travelers. J. Vacat. Mark. 2010, 16, 45-59. [CrossRef]

3. Park, J.; Morrison, A.M.; Wu, B.; Kong, Y. Korean Golf Tourism in China: Place, Perception and Narratives. Sustainability 2018, 10, 1055. [CrossRef]

4. Briassoulis, H. "Sorry golfers, this is not your spot!": Exploring public opposition to golf development. J. Sport Soc. Issues 2010, 34, 288-311. [CrossRef]

5. Kim, J.H.; Ritchie, B.W. Motivation-based typology: An empirical study of golf tourists. J. Hosp. Tour. Res. 2012, 36, 251-280. [CrossRef]

6. Andalusian Government. Decreto 43/2008, de 12 de febrero, regulador de las condiciones de implantación y funcionamiento de campos de golf en Andalucía. BOJA 2008, 41, 9-16.

7. Andalusian Government. Decreto 309/2010, de 15 de junio, por el que se modifica el Decreto 43/2008, de 12 de febrero, regulador de las condiciones de implantación y funcionamiento de campos de golf en Andalucía. BOJA 2010, 119, 9-11.

8. Andalusian Government. Orden de 13 de marzo de 2012, por la que se desarrolla el procedimiento para obtener la declaración de campos de golf de interés turístico en Andalucía. BOJA 2012, 57, 61-70.

9. Wilhelm-Richmann, A.; Cowling, R.M.; Difford, M. Responses of South African land-use planning stakeholders to the New Ecological Paradigm and the Inclusion of Nature in Self scales: Assessment of their potential as components of social assessments. Biol. Conserv. 2014, 180, 206-213. [CrossRef]

10. Minoli, D.M.; Goode, M.M.H.; Metcalfe, A.W. Are sport tourists of an environmental mindset to drive the green? The case of golfers. Tour. Manag. Perspect. 2018, 25, 71-79. [CrossRef]

11. Minoli, D.M.; Smith, M.T. An exploration of golf and voluntary environmental programmes. J. Environ. Plan. Manag. 2011, 54, 871-889. [CrossRef]

12. Completo, F.; Gustavo, N. Golf Tourism Destination Management: Looking for a Sustainable Demand: The Case of Portugal. J. Manag. Sustain. 2014, 4, 142-153. [CrossRef] 
13. Woodside, A.G. Applying systems thinking to sustainable golf tourism. J. Travel Res. 2009, 48, $205-215$. [CrossRef]

14. Aksu, A.; Uçar, Ö.; Kiliçarslan, D. Golf tourism: A research profile and security perceptions in Belek, Anatalya, Turkey. Tourismos 2016, 11, 152-169. [CrossRef]

15. Dai, Z.; Puyana, X.; Han, L. Using assessment of net ecosystem services to promote sustainability of golf course in China. Ecol. Indic. 2016, 63, 165-171. [CrossRef]

16. Enz, C.A.; Canina, L. Competitive pricing in the golf industry. J. Revenue Pricing Manag. 2017, 16, $139-153$. [CrossRef]

17. Han, H.; Yoon, H.; Woods, D.P. Role of environmental consciousness in golfers's decision formation in the traditional and screen-golf industries. J. Qual. Assur. Hosp. Tour. 2016, 17, 290-310.

18. López-Bonilla, L.M.; López-Bonilla, J.M. From the New Environmental Paradigm to the Brief Ecological Paradigm: A revised scale in golf tourism. Anatolia 2016, 27, 227-236. [CrossRef]

19. Ramírez-Hurtado, J.M.; Berbel-Pineda, J.M. Identification of segments for overseas tourists playing golf in Spain: A latent class approach. J. Hosp. Mark. Manag. 2015, 24, 652-680. [CrossRef]

20. Kang, M.; Moscardo, G. Exploring cross-cultural differences in attitudes towards responsible tourist behaviour: A comparison of Korean, British and Australian tourists. Asia Pac. J. Tour. Res. 2006, 11, 303-320. [CrossRef]

21. Li, M. Cross-cultural tourist research: A meta-analysis. J. Hosp. Tour. Res. 2014, 38, 40-77. [CrossRef]

22. Correia, A.; Videira, N.; Alves, I.; Ramires, C.; Subtil, R.; Martins, M.V. Tourism golf scenarios: The Algarve case. Tour. Hosp. Res. 2006, 6, 179-196. [CrossRef]

23. Chen, C.H.; Liu, W.L.; Liaw, S.L. Integrated dynamic policy management methodology and system for strategic environmental assessment of golf course installation policy in Taiwan. Environ. Impact Assess. Rev. 2011, 31, 66-76. [CrossRef]

24. Briassoulis, H. Golf-centered development in coastal Mediterranean Europe: A Soft Sustainability Test. J. Sustain. Tour. 2007, 15, 441-462. [CrossRef]

25. Chen, C.H.; Wu, R.S.; Liu, W.L.; Su, W.R.; Chang, Y.M. Development of a methodology for strategic environmental assessment: Application to the assessment of golf course installation policy in Taiwan. Environ. Manag. 2009, 43, 166-188. [CrossRef] [PubMed]

26. Espejo, C. Campos de golf y medio ambiente: Una interacción necesaria [Golf courses and the environment: A necessary interaction]. Cuadernos de Turismo 2004, 14, 67-111.

27. Vargas-Sánchez, A.; Riquel-Ligero, F. A theoretical approach to the institutional context of the environmental management policies of Andalusian golf courses. Tour. Manag. Stud. 2009, 5, 78-94.

28. Villar, A. Marketization of Mediterranean coastal landscape in Andalusia: The paradigmatic case of Costa del Sol and golf courses. Revista de Estudios Regionales 2013, 96, 215-242.

29. Devitt, D.A.; Morris, R.L.; Kopec, D.; Henry, M. Golf course superintendents' and perceptions toward using reuse water for irrigation in the southwestern United States. HortTechnology 2004, 14, 577-583.

30. Utrero-González, N.; Callado-Muñoz, F.J. Competing for water: Golf courses in semiarid regions. The case in Spain. Water Sci. Technol. Water Supply 2014, 14, 886-897. [CrossRef]

31. Li, F.R.; Yang, S.P.; Yu, D.; Wang, H.M.; Chen, Y.; Peng, Y.N. Environmental pollution analysis and countermeasures of the golf course in Yangzonghai area. Adv. Mater. Res. 2013, 788, 283-287. [CrossRef]

32. Kim, D.; Yoon, J.; Yoo, J.; Kim, S.-J.; Yang, J.E. Status and management strategy of pesticide use in golf courses in Korea. J. Appl. Biol. Chem. 2014, 57, 267-277. [CrossRef]

33. Rice, P.J.; Horgan, B.P.; Hamlin, J.L. Evaluation of individual and combined management practices to reduce the off-site transport of pesticides from golf course turf. Sci. Total Environ. 2017, 583, 72-80. [CrossRef] [PubMed]

34. Neo, H. Sustaining the unsustainable? Golf in urban Singapore. Int. J. Sustain. Dev. World Ecol. 2001, 8, 191-202. [CrossRef]

35. Fox, S.-J.C.; Hockey, P.A.R. Impacts of a South African coastal golf estate on shrubland bird communities. S. Afr. J. Sci. 2007, 103, 27-34.

36. Stodolska, M. Implications of the conditioned attitude model of individual discriminatory behaviour for discrimination in leisure settings. Leis. Sci. 2005, 27, 59-74. [CrossRef] 
37. Larson, L.R.; Whiting, J.W.; Green, G.T. Exploring the influence of outdoor recreation participation on pro-environmental behaviour in a demographically diverse population. Local Environ. 2011, 16, 67-86. [CrossRef]

38. Kil, N.; Holland, S.M.; Stein, T.V. Structural relationships between environmental attitudes, recreation motivations, and environmentally responsible behaviors. J. Outdoor Recreat. Tour. 2014, 7-8, 16-25. [CrossRef]

39. Larson, L.R.; Stedman, R.C.; Cooper, C.B.; Decker, D.J. Understanding the multidimensional structure of pro-environmental behavior. J. Environ. Psychol. 2015, 43, 112-124. [CrossRef]

40. Gamborg, C.; Jensen, F.S. Attitudes towards recreational hunting: A quantitative survey of the general public in Denmark. J. Outdoor Recreat. Tour. 2017, 17, 20-28. [CrossRef]

41. Larson, L.R.; Usher, L.E.; Chapmon, T. Surfers as environmental stewards: Understanding plae-protecting behavior at Cape Hatteras National Seashore. Leis. Sci. 2017, 1-24. [CrossRef]

42. Etminani-Ghasrodashti, R.; Paydar, M.; Ardeshiri, A. Recreational cycling in a coastal city: Investigating lifestyle, attitudes and built environment in cycling behavior. Sustain. Cities Soc. 2018, 39, 241-251. [CrossRef]

43. Juvan, E.; Dolnicar, S. The attitude-behaviour gap in sustainable tourism. Ann. Tour. Res. 2014, 48, 76-95. [CrossRef]

44. Juvan, E.; Dolnicar, S. Drivers of pro-environmental tourist behaviours are not universal. J. Clean Prod. 2017, 166, 879-890. [CrossRef]

45. Hall, C.M.; Dayal, N.; Majstorović, D.; Mills, H.; Paul-Andrews, L.; Wallace, C.; Truong, V.D. Accommodation consumers and providers' attitudes, behaviours and practices for sustainability: A systematic review. Sustainability 2016, 8, 625. [CrossRef]

46. Poudel, S.; Nyaupane, G.P. Understanding environmentally responsible behaviour of ecotourists: The Reasoned Action Approach. Tour. Plan. Dev. 2017, 14, 337-352. [CrossRef]

47. Baird, T.; Hall, C.M.; Castka, C. New Zealand winegrowers attitudes and behaviours towards wine tourism and sustainable winegrowers. Sustainability 2018, 10, 797. [CrossRef]

48. López-Bonilla, J.M.; López-Bonilla, L.M. Environmental orientation in tourism: The RTEO scale. Curr. Issues Tour. 2012, 15, 591-596. [CrossRef]

49. Minoli, D.M.; Goode, M.M.H.; Smith, M.T. Are eco labels profitably employed in sustainable tourism? A case study on Audubon Certified Golf Resorts. Tour. Manag. Perspect. 2015, 16, 207-216. [CrossRef]

50. Correia, A.; Pintassilgo, P. The golf player's motivation: The Algarve case. Tour. Hosp. Res. 2006, 6, $227-238$. [CrossRef]

51. Petrick, J.F.; Backman, S.J.; Bixler, R.; Norman, W. Analysis of golfer motivation and constraints by experience. J. Leis. Res. 2001, 33, 56-70. [CrossRef]

52. Correia, A.; Barros, C.P.; Silvestre, A.L. Golf tourism repeat choice behaviour in the Algarve: A mixed logit approach. Tour. Econ. 2007, 13, 111-127. [CrossRef]

53. Petrick, J.F.; Backman, S.J. An examination of the construct of perceived value for the prediction of golf travelers' intentions to revisit. J. Travel Res. 2002, 41, 38-45. [CrossRef]

54. Humphreys, C.J. Understanding how sporting characteristics and behaviours influence destination selection: A grounded theory study of golf tourism. J. Sport Tour. 2014, 19, 29-54. [CrossRef]

55. Moital, M.; Dias, N.R.; Machado, D.F.C. A cross national study of golf tourists' satisfaction. J. Destin. Mark. Manag. 2013, 2, 39-45. [CrossRef]

56. Petrick, J.F.; Backman, S.J. An examination of determinants of golf travelers' satisfaction. J. Travel Res. 2002, 40, 252-258. [CrossRef]

57. Correia, A.; Oliveira, N.; Silva, F. Bridging perceived destination image and market segmentation-An application to golf tourism. Eur. J. Tour. Res. 2009, 28, 41-69.

58. Garau-Vadell, J.B.; Borja-Solé, L. Golf in mass tourism destinations facing seasonality: A longitudinal study. Tour. Rev. 2008, 63, 16-24. [CrossRef]

59. McGinnis, L.P.; Gentry, J.W.; McQuillan, J. Ritual-based behavior that reinforces hegemonic masculinity in golf: Variations in women golfers' responses. Leis. Sci. 2008, 31, 19-36. [CrossRef]

60. Reis, H.; Correia, A. Gender asymmetries in golf participation. J. Hosp. Mark. Manag. 2013, $22,67-91$. [CrossRef]

61. Wood, L.; Danylchuk, K. Playing our way: Contributions of social groups to women's continued participation in golf. Leis. Sci. 2011, 33, 366-381. [CrossRef] 
62. Kim, S.S.; Kim, J.H.; Ritchie, B.W. Segmenting overseas golf tourists by the concept of specialization. J. Travel Tour. Mark. 2008, 25, 199-217. [CrossRef]

63. Shani, A.; Wang, Y.; Hutchinson, J.; Lai, F. Applying expenditure-based segmentation on special-interest tourists: The case of golf travelers. J. Travel Res. 2009, 49, 337-350. [CrossRef]

64. Wilson, J.; Thilmany, D. Golfers in Colorado: The role of golf in recreational and tourism lifestyles and expenditures. J. Travel Tour. Mark. 2006, 20, 127-144. [CrossRef]

65. Dolnicar, S.; Crouch, G.I.; Long, P. Environmentally friendly tourists: What do we really know about them? J. Sustain. Tour. 2008, 16, 197-210. [CrossRef]

66. Lee, W.H.; Moscardo, G. Understanding the impact of ecotourism resort experiences on tourists' environmental attitudes and behavioural intentions. J. Sustain. Tour. 2005, 13, 546-565. [CrossRef]

67. Roberts, J.A.; Bacon, D.R. Exploring the subtle relationships between environmental concern and ecologically conscious consumer behavior. J. Bus. Res. 1997, 40, 79-89. [CrossRef]

68. Claudy, M.C.; Peterson, M.; O'Driscoll, A. Understanding the attitude-behavior gap for renewable energy systems using behavioral reasoning theory. J. Macromark. 2013, 33, 273-287. [CrossRef]

69. Hwang, K.; Lee, J. Antecedents and Consequences of Ecotourism Behavior: Independent and Interdependent Self-Construals, Ecological Belief, Willingness to Pay for Ecotourism Services and Satisfaction with Life. Sustainability 2018, 10, 789. [CrossRef]

70. Lee, Y.K. A Comparative Study of Green Purchase Intention between Korean and Chinese Consumers: The Moderating Role of Collectivism. Sustainability 2017, 9, 1930. [CrossRef]

71. Moraes, C.; Carrigan, M.; Szmigin, I. The coherence of inconsistencies: Attitude-behaviour gaps and new consumption communities. J. Mark. Manag. 2012, 28, 103-128. [CrossRef]

72. Schill, M.; Shaw, D. Recycling today, sustainability tomorrow: Effects of psychological distance on behavioural practice. Eur. Manag. J. 2016, 34, 349-362. [CrossRef]

73. Anvar, M.; Venter, M. Attitudes and purchase behaviour of green products among Generation $Y$ consumers in South Africa. Mediterr. J. Soc. Sci. 2014, 5, 183-194. [CrossRef]

74. Chen, C.C.; Chen, C.V.; Tung, Y.C. Exploring the Consumer Behavior of Intention to Purchase Green Products in Belt and Road Countries: An Empirical Analysis. Sustainability 2018, 10, 854. [CrossRef]

75. Duerden, M.D.; Witt, P.A. The impact of direct and indirect experiences on the development of environmental knowledge, attitudes, and behavior. J. Environ. Psychol. 2010, 30, 379-392. [CrossRef]

76. Nguyen, T.N.; Lobo, A.; Greenland, S. Energy efficient household appliances in emerging markets: The influence of consumers' values and knowledge on their attitudes and purchase behaviour. Int. J. Consum. Stud. 2017, 41, 167-177. [CrossRef]

77. Wu, K.S.; Huang, D.M.; Teng, Y.M. Environmental concerns, attitudes and behavior intention toward patronize green restaurant. Life Sci. J. 2013, 10, 2329-2340.

78. Choi, A.S.; Fielding, K.S. Environmental attitudes as WTP predictors: A case study involving endangered species. Ecol. Econ. 2013, 89, 24-32. [CrossRef]

79. Ebreo, A.; Hershey, J.; Vining, J. Reducing solid waste: Linking recycling to environmentally responsible consumerism. Environ. Behav. 1999, 31, 107-135. [CrossRef]

80. Kotchen, M.J.; Reiling, S.D. Environmental attitudes, motivations, and contingent valuation of nonuse values: A case study involving endangered species. Ecol. Econ. 2000, 32, 93-107. [CrossRef]

81. Paço, A.; Lavrador, T. Environmental knowledge and attitudes and behaviours towards energy consumption. J. Environ. Manag. 2017, 197, 384-392. [CrossRef] [PubMed]

82. Cleveland, M.; Kalamas, M.; Laroche, M. "It's not easy being green”: Exploring green creeds, green deeds, and internal environmental locus of control. Psychol. Mark. 2012, 29, 293-305. [CrossRef]

83. Gamba, R.J.; Oskamp, S. Factors influencing community residents' participation in commingled curbside recycling programs. Environ. Behav. 1994, 26, 587-612. [CrossRef]

84. Oskamp, S.; Harrington, M.J.; Edwards, T.C.; Sherwood, D.L.; Okuda, S.M.; Swanson, D.C. Factors influencing household recycling behavior. Environ. Behav. 1991, 23, 494-519. [CrossRef]

85. Sánchez, M.; López-Mosquera, N.; Lera-López, F. Improving pro-environmental behaviours in Spain. The role of attitudes and sociodemographic and political factors. J. Environ. Policy Plan. 2016, 18, 47-66. [CrossRef]

86. Choi, R.; Ritchie, B.W.; Fielding, K.S. A Mediation model of air travelers' voluntary climate action. J. Travel Res. 2016, 55, 709-723. [CrossRef] 
87. Kim, A.K.; Airey, D.; Szivas, E. The multiple assessment of interpretation effectiveness: Promoting visitors' environmental attitudes and behavior. J. Travel Res. 2011, 50, 321-334.

88. Lee, T.H.; Jan, F.H. The influence of recreation experience and environmental attitude on the environmentally responsible behavior of community-based tourists in Taiwan. J. Sustain. Tour. 2015, 23, 1063-1094. [CrossRef]

89. Li, L.; Wang, L.Y. An empirical study on the effect of eco-tourism visitors' environmental attitudes on environmental behavior. Appl. Ecol. Environ. Res. 2017, 15, 91-101. [CrossRef]

90. Ong, F.; Musa, G. An examination of recreational divers' underwater behaviour by attitude-behaviour theories. Curr. Issues Tour. 2011, 14, 779-795. [CrossRef]

91. Prillwitz, J.; Barr, S. Moving towards sustainability? Mobility styles, attitudes and individual travel behaviour. J. Transp. Geogr. 2011, 19, 1590-1600. [CrossRef]

92. Goh, E.; Ritchie, B.; Wang, J. Non-compliance in national parks: An extension of the theory of planned behaviour model with pro-environmental values. Tour. Manag. 2017, 59, 123-127. [CrossRef]

93. Bergin-Seers, S.; Mair, J. Emerging green tourists in Australia: Their behaviours and attitudes. Tour. Hosp. Res. 2009, 9, 109-119. [CrossRef]

94. McDonald, S.; Oates, C.J.; Alevizou, P.J.; Young, C.W.; Hwang, K. Individual strategies for sustainable consumption. J. Mark. Manag. 2012, 28, 445-468. [CrossRef]

95. McKercher, B.; Tse, T.S. Is intention to return a valid proxy for actual repeat visitation? J. Travel Res. 2012, 51, 671-686. [CrossRef]

96. Kinnear, T.C.; Taylor, J.R.; Ahmed, S.A. Ecologically concerned consumers: Who are they? J. Mark. 1974, 38, 82-103. [CrossRef]

97. Dunlap, R.E.; Van Liere, K.D. The 'new environmental paradigm': A proposed instrument and preliminary results. J. Environ. Educ. 1978, 9, 10-19. [CrossRef]

98. Jackson, S. Attitudes towards the environment and ecotourism of stakeholders in the UK tourism industry with particular reference to ornithological tour operators. J. Ecotour. 2007, 6, 34-66. [CrossRef]

99. Kaiser, F.J.; Wölfing, S.; Fuhrer, U. Environmental attitude and ecological behaviour. J. Environ. Psychol. 1999, 19, 1-19. [CrossRef]

100. Wolf-Watz, D.; Sandell, K.; Fredman, P. Environmentalism and tourism preferences: A study of outdoor recreationists in Sweden. Scand. J. Hosp. Tour. 2011, 11, 190-204. [CrossRef]

101. Eagly, A.H.; Chaiken, S. The Psychology of Attitudes; Harcourt Brace College Publishers: Orlando, FL, USA, 1993.

102. Petty, R.E.; Cacioppo, J.T. Attitudes and Persuasion: Classic and Contemporary Approaches; Brown Shoe Fit Co.: Duduque, IA, USA, 1981.

103. Fishbein, M.; Ajzen, I. Belief, Attitude, Intention and Behaviour: An Introduction to Theory and Research; Addison-Wesley Publishing: Menlo Park, CA, USA, 1975.

104. Fishbein, M.; Ajzen, I. Predicting and understanding consumer behavior: Attitude-behavior correspondence. In Understanding Attitudes and Predicting Social Behavior; Ajzen, I., Fishbein, M., Eds.; Prentice-Hall: Englewood Cliffs, NJ, USA, 1980; pp. 148-172.

105. Venaik, S.; Brewer, P. The common threads of national cultures. Australas. Mark. J. 2015, 23, 75-85. [CrossRef]

106. Kraus, S.; Meier, F.; Eggers, F.; Bouncken, R.B.; Schuessler, F. Standardisation vs. adaption: A conjoint experiment on the influence of psychic, cultural and geographical distance on international marketing mix decisions. Eur. J. Int. Manag. 2016, 10, 127-156. [CrossRef]

107. Kim, D.Y.; Wen, L.; Doh, K. Does cultural difference affect customer's response in a crowded restaurant environment? A comparison of American versus Chinese customers. J. Hosp. Tour. Res. 2010, 34, 103-123. [CrossRef]

108. Kankaraš, M.; Moors, G. Cross-national and cross-ethnic differences in attitudes: A case of Luxembourg. Cross-Cult. Res. 2012, 46, 224-254. [CrossRef]

109. Minkov, M.; Hofstede, G. Clustering of 316 European regions on measures of values: Do Europe's countries have national cultures? Cross-Cult. Res. 2014, 48, 144-176. [CrossRef]

110. Smith, P.B. Nations, cultures and individuals: New perspectives and old dilemmas. J. Cross-Cult. Psychol. 2004, 35, 6-12. [CrossRef]

111. Peterson, M.F.; Smith, P.B. Social structures and processes in cross-cultural management. In The Handbook of Cross-Cultural Management Research; Smith, P.B., Peterson, M.F., Thomas, D.C., Eds.; Sage: Thousand Oaks, CA, USA, 2008; pp. 35-58. 
112. Laing, J.H.; Crouch, G.I. Extraordinary journeys: An exploratory cross-cultural study of tourists on the frontier. J. Vacat. Mark. 2005, 11, 209-223. [CrossRef]

113. Bechtel, R.B.; Verdugo, V.C.; Pinheiro, J.Q. Environmental belief systems: United States, Brazil, and Mexico. J. Cross-Cult. Psychol. 1999, 30, 122-128. [CrossRef]

114. Cordano, M.; Welkomer, S.; Scherer, R.F.; Pradenas, N.; Parada, V. Understanding cultural differences in the antecedents of pro-environmental behavior: A comparative analysis of business students in the United State and Chile. J. Environ. Educ. 2010, 41, 224-238. [CrossRef]

115. Hudson, S.; Ritchie, J.R.B. Cross-cultural tourist behavior: An analysis of tourist attitudes towards the environment. J. Travel Tour. Mark. 2001, 10,1-22. [CrossRef]

116. Dunlap, R.E.; Van Liere, K.D.; Mertig, A.G.; Jones, R.E. Measuring endorsement of the New Ecological Paradigm: A revised NEP scale. J. Soc. Issues 2000, 56, 425-442. [CrossRef]

117. Uriely, N.; Reichel, A.; Shani, A. Ecological orientation of tourists: An empirical investigation. Tour. Hosp. Res. 2007, 7, 161-175. [CrossRef]

118. Baroudi, J.J.; Orlikowski, W.J. A short-form measure of user information satisfaction: A psychometric evaluation and notes on use. J. Manag. Inf. Syst. 1988, 4, 44-59. [CrossRef]

119. Peter, J. Reliability: A review of psychometric basics and recent marketing practices. J. Mark. Res. 1979, 16, 6-17. [CrossRef]

120. López-Bonilla, J.M.; López-Bonilla, L.M. Sensation-seeking profiles and personal innovativeness information technology. Soc. Sci. Comput. Rev. 2012, 30, 434-447. [CrossRef]

121. Chin, W.W. The Partial Least Squares approach to structural equation modeling. In Modern Methods for Business Research; Marcoulides, G.A., Ed.; Lawrence Erlbaum Associates: Hillsdale, NJ, USA, 1998; pp. 295-336.

122. Keil, M.; Tan, B.C.Y.; Wei, K.K.; Saarinen, T.; Tuunainen, V.; Wassenaar, A. A cross-cultural study scalation of commitment behavior in software projects. MIS Q. 2000, 24, 299-325. [CrossRef]

123. Fornell, C.; Larcker, D. Evaluating structural equation models with unobservable variables and measurement error. J. Mark. Res. 1981, 18, 39-50. [CrossRef]

124. Falk, R.F.; Miller, N.B. A Primer for Soft Modeling; The University of Akron Press: Akron, OH, USA, 1992.

125. Carrus, G.; Bonaiuto, M.; Bonnes, M. Environmental concern, regional identity, and support for protected areas in Italy. Environ. Behav. 2005, 37, 237-257. [CrossRef]

126. Stern, P.C.; Oskamp, S. Managing scarce environmental resources. In Handbook of Environmental Psychology; Stokols, D., Altman, I., Eds.; Wiley: New York, NY, USA, 1987; pp. 1043-1088.

127. Marcoulides, G.A.; Saunders, C. PLS: A silver bullet? MIS Q. 2006, 30, 3-4. [CrossRef]

128. Hair, J.F.; Ringle, C.M.; Sarstedt, M. PLS-SEM: Indeed a silver bullet. J. Mark. Theory Pract. 2011, 19, $139-151$. [CrossRef]

(c) 2018 by the authors. Licensee MDPI, Basel, Switzerland. This article is an open access article distributed under the terms and conditions of the Creative Commons Attribution (CC BY) license (http://creativecommons.org/licenses/by/4.0/). 